\title{
SEWA RAHIM ANTARA PRO DAN KONTRA
}

\author{
Fika Aufani kumala \\ Universitas Islam Negeri Sunan Kalijaga Yogyakarta, Indonesia \\ auvanifika@gmail.com
}

Received:22-04-2020; Revised:30-11-2020; Accepted: 20-12-2020;

\section{ABSTRACT}

One of the marriage's aim is to have offspring. It is commonly coveted by newly married couples. Various methods are used, but reality not all spouses are able to have a biological child. This can be caused by infertility or diseases. Nowadays, medical technology gives alternative way for intended parent with surrogate mother. However, this practice has gained attention among society and scholars. Some of them agree this practice and the others forbid it. Their opinions who forbid surrogacy more observe to social aspect. This practice can attract to the standard of animal life and the occurrence of mixing nasab. In the ethical aspect, inserting seeds into another woman's womb is forbidden (harām) based on the hadīth of Prophet Mohammed Saw. This practice can eliminate the nature of motherhood and damage the order of life. The opinion that allows practice of surrogacy is more emphasis on the concept of emergency, where the desire to get offspring is high. The results of this research indicate that the practice of surrogate mother cannot be categorized as an emergency and urgent matter because the subject of this practice is not fill requirement.

Keywords: Surrogate Mother, Children, Disease, Emergency.

\section{INTISARI}

Salah satu tujuan dari perkawinan adalah untuk memperoleh keturunan, hal ini lazim diinginkan bagi pasangan suami istri yang baru menikah. Berbagai cara dilakukan untuk dapat memiliki anak, namun dalam kenyataannya tidak semua pasangan suami istri mampu menghasilkan keturunannya sendiri, hal ini dapat disebabkan karena adanya kelainan atau cacat/penyakit yang membuat pasangan tersebut tidak dapat mengahasilkan keturunan. Seiring dengan perkembangan zaman, teknologi yang semakin berkembang lantas memberikan alternatif dengan jalan sewa rahim bagi pasangan yang ingin memiliki keturunannya sendiri namun terhalang oleh suatu penyakit atau kelainan. Namun hadirnya praktik sewa rahim ini juga menjadi perdebatan di berbagai kalangan masyarakat dan ulama, ada yang membolehkan juga ada yang melarangnya, Diantara pendapat yang melarangnya lebih meninjau dari segi sosial, dapat menarik ketaraf kehidupan binatang dan terjadinya pencampuran nasab. Segi etika, bahwa memasukkan benih ke rahim wanita lain hukumnya haram berdasarkan hadis Nabi serta bagi seorang wanita bisa menghilangkan sifat keibuannya dan dapat merusak tatanan kehidupan. Adapun pendapat yang membolehkan lebih menekankan pada konsep darurat, dimana keinginan untuk memperoleh keturunan sangatlah besar. Namun hasil dari penelitian ini mengkaji bahwa praktik sewa rahim tidak dapat dikategorikan sebagai hal yang darurat dan mendesak, karena pelaku praktik sewa rahim tidak memenuhi persyaratan sebagai seseorang yang bisa dikatakan dalam kondisi darurat. Kata Kunci: Sewa Rahim, Anak, Penyakit, Kelainan. 


\section{A. Pendahuluan}

Allah menciptakan manusia di muka bumi ini tidak lain untuk menjadikannya sebagai khalifah. Dan di antara yang menjadi tanda-tanda dari kebesaran Allah SWT ialah Dia menciptakan manusia dengan berpasang-pasangan, dan menghasilkan keturunan yang banyak. Di antara tujuan pernikahan yaitu untuk memperoleh keturunan yang sah dan bersih, memberikan kepastian nasab dan memelihara kelestariannya, dengan demikian tiap-tiap keluarga akan saling mengenal antara anak dengan bapaknya, dan terhindar dari tercampur aduknya antara satu keluarga dengan yang lain, maka estafet generasi manusia akan terpelihara kejelasannya.

Setiap pasangan suami dan istri pasti mendambakan seorang anak untuk melestarikan keturunannya, hal tersebut wajar dan manusiawi, bahkan menjadi salah satu tujuan dari perkawinan. Namun, pada kenyataannya tidak semua pasangan suami dan istri mampu menghasilkan anak dari keturunannya sendiri, hal ini dapat disebabkan karena pasangan memiliki kelainan atau karena penyakit, bisa juga karena ketidaksuburan dari pasangan. Dengan perkembangan teknologi saat ini salah satu cara yang dapat ditempuh adalah melakukan inseminasi buatan atau dengan cara menyewa rahim seseorang yang biasa disebut dengan Surrogate Mother.

Pada awalnya Surrogate Mother terjadi karena istri tidak dapat mengandung disebabkan suatu hal terjadi pada rahimnya, akan tetapi pada perkembangan selanjutnya terjadi pergeseran makna dan substansi, dari substansi awal sebagai alternatif kelainan medis (karena cacat bawaan atau karena penyakit) kemudian sudah beralih ke alasan kosmetik dan estetika (ingin menjaga bentuk tubuh agar tetap ideal), sedangkan pihak yang di sewa rahimnya menjadikan hal tersebut sebagai ladang bisnis baru dengan menyewakan rahimnya sebagai alat pencari nafkah (terutama bagi masyarakat dengan ekonomi yang rendah). ${ }^{1}$

Secara hukum anak hasil program bayi tabung baik yang dilakukan oleh pasangan suami istri maupun melalui sewa rahim menimbulkan perdebatan dan persoalan hukum, khususnya bagi anak yang dilahirkan tersebut, siapakah yang berhak menjadi ibunya. Bagaimana kedudukan hukumnya dan bagaimana hak-haknya baik dipandang melalui hukum positif di Indonesia maupun hukum Islam. Dari berbagai persoalan tersebut, penulis merumuskan empat pokok permasalahan yang akan dibahas dalam tulisan ini diantaranya; pertama penulis akan menjelaskan pengertian dari sewa rahim, kemudian membahas tentang bagaimana praktik sewa rahim jika dilihat baik dari sudut pandang hukum yuridis maupun hukum Islam, dan terakhir merupakan subbab analasis penulis terkait kasus praktik sewa rahim.

\section{B. Metode Penelitian}

Penelitian ini termasuk ke dalam jenis penelitian kepustakaan (library research), yakni dengan mengumpulkan data dan informasi dari berbagai macam material kepustakaan seperti buku-buku, artikel, dokumen dll. Dalam menganalisis penelitian ini penulis menggunakan pendekatan normatif yuridis, dikaji dan dihimpun menjadi sebuah penelitian yang utuh.

\section{Hasil dan Pembahasan}

\section{Pengertian Sewa Rahim}

Sebelum membahas kepada pengertian sewa rahim maka perlu kita ketahui bahwa penciptaan janin terjadi dimulai dari bertemunya sel telur dengan sel sperma yang merupakan

1 Desriza Ratman, Surrogate Mother, dalam Perspektif Etika dan Hukum, (Jakarta: Elex Media Komputindo, 2012), 38. 
proses alamiah yang biasa terjadi dalam reproduksi manusia. Apabila terdapat gangguan dalam proses reproduksi yang mengakibatkan tidak dapat terjadinya proses pembuahan, maka teknologi medis memiliki alternatif dengan menggunakan program bayi tabung.

Proses pembuahan dalam sebuah alat (fertilisasi in vitro) bisa disebabkan karena dua kondisi. Yang pertama karena tertutupnya uterus yang merupakan tempat bercampurnya sel sperma dan sel telur. Prosesnya dengan cara mengeluarkan sel telur dari istri yang kemudian dicampurkan dengan sel sperma suami ke dalam sebuah tabung, setelah terbentuknya zigot dan menjadi sebuah janin yang berkembang, maka kemudian disimpan dan dipindahkan lagi ke dalam rahim istri untuk terjadinya kehamilan. Pada kondisi yang kedua, yaitu karena terdapat kecacatan atau gangguan dalam rahim istri. Prosesnya sama dengan cara yang pertama akan tetapi setelah terbentuknya zigot dan menjadi janin kemudian dipindahkan dan dititipkan pada rahim perempuan lain yang bukan istrinya (rahim pinjaman), atau yang biasa disebut dengan sewa rahim. ${ }^{2}$ Karena proses pemindahan janin tersebut melalui sebuah alat berbentuk tabung di luar tubuh manusia, maka janin tersebut dinamakan bayi tabung.

Sewa rahim merupakan sebuah alternatif ketika istri memiliki kecacatan dalam rahimnya, sehingga rahimnya tidak bisa untuk mengandung dan melahirkan bayinya. Ibu Pengganti/Surrogate mother adalah seorang wanita yang mengandung anak atas kepentingan orang lain dan juga memberikan hak-haknya sebagai orang tua kepada orang lain tersebut, atau seorang wanita mengandung yang anak benihnya berasal dari pasangan lain dan kemudian setelah melahirkan wanita tersebut memberikan hak atas pengasuhan anak yang telah dilahirkannya kepada pasangan yang menitipkan benihnya tersebut. ${ }^{3}$

Pengertian lain dari surrogate mother adalah seorang wanita yang menyetujui untuk mengandung dan melahirkan anak dari pasangan lain yang tidak dapat memiliki keturunan dikarenakan sang istri infertile atau secara fisik tidak mampu membawa janin dalam kandungannya, yang didasarkan atas sebuah perjanjian atau pembayaran.

Fred Amelen menyatakan bahwa surrogate mother adalah seorang wanita yang telah mengikatkan dirinya kepada pasangan lain untuk menjadi hamil dan mengandung dari benih pasangan lain tersebut yang proses pembuahannya diluar rahim sampai melahirkan dan sesuai dengan kesepakatan bayi tersebut diserahkan kepada pasangan yang menitipkan benihnya tersebut dan diganti dengan sebuah imbalan sesuai yang telah disepakati sebelumnya. ${ }^{4}$

Penyewaan rahim dapat dilakukan dalam bentuk-bentuk sebagai berikut:

1. Sel telur istri (ovum) disenyawakan dengan sperma suami, yang kemudian hasil pembuahan tersebut dimasukkan ke dalam rahim perempuan lain. Kaedah ini diterapkan ketika istri memiliki benih yang bagus akan tetapi rahimnya dibuang karena pembedahan, kecacatan, maupun karena penyakit yang kronik atau sebab-sebab lain.

\footnotetext{
${ }^{2}$ Abu Abdurrahman Adil Bin Yusuf Al Azazi, Pandangan Al-Qur'an dan Ilmu Kedokteran, diterjemahkan oleh Zaenal Mutaqin, dari Fathul Karim Bi Ahkamil Hamil wal janin, Darul Ibnu Al-Jauziyah, Cairo, Pustaka Rahmat, Bandung, Cetakan I, Oktober 2009, 114.

${ }^{3}$ Pendapat Bryan A. Garner, Black's Law Dictionary, $8^{\text {th }}$ Edition, (St. Paul: West Thomson, 2004) Sebagaimana dikutip oleh Sonny Dewi Judiasih dkk., Aspek Hukum Sewa Rahim dalam Perspektif Hukum Indonesia, (Bandung: PT Refika Aditama, 2016 ), 11.

${ }^{4}$ Pendapat Fred Amelen, Kapita Selekta Hukum Kesehatan, sebagaimana dikutip oleh Sonny Dewi Judiasih dkk., Aspek Hukum Sewa Rahim dalam Perspektif Hukum Indonesia, (Bandung: PT Refika Aditama, 2016 ), 12.
} 
2. Sama dengan yang pertama tetapi benih yang telah disenyawakan tersebut dibekukan dan dimasukkan ke dalam rahim ibu tumpang selepas kematian pasangan suami istri itu.

3. Ovum istri disenyawakan dengan sperma lelaki lain yang bukan suaminya dan dimasukkan ke dalam rahim perempuan lain. Hal ini dilakukan ketika suami mandul dan istri terdapat kecacatan di dalam rahimnya tetapi memiliki istri benih yang baik.

4. Sperma suami disenyawakan dengan ovum perempuan lain yang bukan istrinya, yang kemudian dimasukkan ke dalam rahim perempuan lain. Hal ini disebabkan karena sang istri ditimpa penyakit pada ovarium dan rahimnya tidak mampu untuk mengandung janin, atau istri telah mencapai tahap putus haid/menopause.

5. Sperma suami disenyawakan dengan ovum istri yang kemudian dimasukkan ke dalam rahim istri yang lain dari suaminya. Dalam keadaan ini istri yang lain mampu mengandung anak suaminya dari istri yang tidak dapat hamil.

Sewa rahim merupakan teknik bayi tabung (fertilisasi in vitro) di mana sperma dan ovum dari pasangan suami-istri yang diproses dalam sebuah alat (vitro) kemudian dimasukkan ke dalam rahim perempuan lain bukan ke dalam rahim istri pemilik ovum tersebut. Perempuan yang telah bersedia dititipkan embrio dari pasangan suami-istri tersebut disebut sebagai surrogate mother, umumnya perjanjian antara surrogate mother dengan pasangan suami-istri yang ingin menggunakan jasanya biasa disebut dengan intended parent. Surrogate mother diberikan biaya untuk semua kebutuhannya selama proses mengandung sampai dengan melahirkan dan setelah melahirkan. Setelah melahirkan surrogate mother harus menyerahkan anak tersebut kepada intended parent.

\section{Pelaksanaan Sewa Rahim dalam Perspektif Hukum Positif}

Negara Indonesia secara spesifik tidak memiliki aturan tentang praktik sewa rahim/surrogate mother. Praktik hukum di Indonesia menyiratkan bahwa praktik surrogate mother dilarang dilakukan, namun pada kenyataannya pelaksanaan sewa rahim ini terjadi secara diam-diam di beberapa daerah dengan cara kekeluargaan. Permasalahan akan muncul ketika Ibu Pengganti tidak mau menyerahkan bayinya kepada para penyewa. Di Indonesia setidaknya ada 3 aturan yang membahas terkait dengan program kehamilan di luar cara alamiah, dan muatan pasalnya menyiratkan bahwa praktik penyewaan rahim adalah dilarang atau tidak diperbolehkan. Hal tersebut dipertegas dengan adanya sanksi pidana bagi yang melakukan praktik tersebut, yakni dalam Pasal 82 UU No. 23 Tahun 1992 tentang Kesehatan menegaskan "Barang siapa dengan sengaja melakukan upaya kehamilan diluar cara alamiyang tidak sesuai dengan ketentuan dipidana dengan pidana penjara paling lama 5 (lima) tahun atau pidana denda paling banyak Rp. 100.000.000,00 (seratus juta rupiah)."

Beberapa peraturan yang secara tidak langsung menyiratkan tentang praktik sewa rahim/ surrogate mother dapat dilihat di beberapa ketentuan sebagai berikut:

a. Undang-Undang No. 36 Tahun 2009 tentang Kesehatan

Undang-undang ini merupakan pembaruan dari Undang-Undang No. 23 Tahun 1992 Tentang Kesehatan. Meskipun sifatnya memperbarui, akan tetapi ketentuan dalam UndangUndang No. 23 Tahun 1992 tetap berlaku selama tidak bertentangan. Pelaksanaan program kehamilan di luar cara alamiah hanya dapat dilakukan oleh pasangan suami-istri yang sah yang tidak dapat memperoleh keturunan secara alami, program kehamilan di luar cara alamiah ini

\footnotetext{
${ }^{5}$ UU No. 23 Tahun 1992 tentang Kesehatan.
} 
merupakan upaya terakhir melalui ilmu pengetahuan dan teknologi kedokteran. Berdasarkan Pasal 16 ayat (1) Undang-Undang No. 23 Tahun 1992 Tentang Kesehatan menyatakan bahwa:

"Kehamilan di luar cara alami dapat dilaksanakan sebagai upaya terakhir untuk membantu suami istri mendapatkan keturunan".

Dalam Undang-Undang ini larangan terkait praktik sewa rahim dapat kita telisik dalam Pasal 127 ayat (1) dimana pasal tersebut membahas tentang syarat dari dilangsungkannya program kehamilan di luar cara alami, dalam pasal tersebut menyatakan bahwa upaya kehamilan di luar cara alamiah hanya dapat dilakukan pasangan suami istri yang sah dengan ketentuan: ${ }^{6}$

Hasil pembuahan sperma dan ovum dari suami dan istri yang bersangkutan ditanamkan dalam rahim istri dari mana ovum berasal;

Dilakukan oleh tenaga kesehatan yang mempunyai keahlian dan kewenangan untuk itu; dan

Pada fasilitas pelayanan tertentu.

Ayat (2): Ketentuan mengenai persyaratan kehamilan di luar cara alamiah sebagaimana dimaksud pada ayat (1) diatur dengan Peraturan Pemerintah.

Secara gramatikal dapat disimpulkan bahwa yang diperbolehkan dalam hukum Indonesia adalah pembuahan sel telur dengan sperma dari suami-istri yang sah dan janin tersebut dikembalikan ke dalam rahim sang istri, yang dikenal dengan bayi tabung. Dengan demikian, dalam hukum Indonesia upaya kehamilan diluar cara alamiah melalui konsep ibu pengganti (surrogate mother) atau sewa rahim yakni tidak dibenarkan. Dalam Pasal 72 huruf B lebih lanjut dijelaskan bahwa setiap orang berhak menentukan kehidupan reproduksinya dan bebas dari diskriminasi, paksaan, dan/atau kekerasan yang menghormati nilai-nilai luhur yang tidak merendahkan martabat manusia sesuai dengan norma agama.

\section{b. Keputusan Menteri Kesehatan RI No. 72/Menkes/Per/II/1999 tentang} Penyelenggaraan Teknologi Reproduksi Buatan

Peraturan ini berisikan tentang ketentuan umum, perizinan, pembinaan, dan pengawasan, Ketentuan Peralihan dan Penutup. Keputusan Menteri Kesehatan RI No. 72 ini dalam point ke-4 menyatakan dengan tegas larangan praktik surogasi dalam bentuk apapun.

Adapun keputusan-keputusan tersebut diantaranya: ${ }^{7}$

1. Pelayanan teknik reprodukasi buatan hanya dapat dilakukan dengan sel sperma dan sel telur pasangan suami-istri yang bersangkutan.

2. Pelayanan reproduksi buatan merupakan bagian dari pelayanan infertilitas, sehingga sehingga kerangka pelayanannya merupakan bagian dari pengelolaan pelayanan infertilitas secara keseluruhan.

3. Embrio yang dipindahkan ke rahim istri dalam satu waktu tidak lebih dari 3, boleh dipindahkan 4 embrio dalam keadaan:

a. Rumah sakit memiliki 3 tingkat perawatan intensif bayi baru lahir;

b. Pasangan suami istri sebelumnya sudah mengalami sekurang-kurangnya 2 kali prosedur teknologi reproduksi yang gagal;

c. Istri berumur lebih dari 35 tahun.

\footnotetext{
${ }^{6}$ Undang-Undang Republik Indonesia Nomor 36 Tahun 2009 tentang Kesehatan.

${ }^{7}$ Keputusan Menteri Kesehatan RI No. 72/Menkes/Per/II/1999 tentang Penyelenggaraan Teknologi Reproduksi Buatan.
} 
4. Dilarang melakukan surogasi dalam bentuk apapun.

5. Dilarang melakukan jual beli spermatozoa, ovum atau embrio.

6. Dilarang menghasilkan embrio manusia semata-mata untuk penelitian atau sejenisnya terhadap embrio manusia kecuali tujuannya telah dirumuskan dengan sangat jelas.

7. Dilarang melakukan penelitian dengan atau pada embrio manusia dengan usia lebih dari 14 hari setelah fertilisasi.

8. Sel telur yang telah dibuahi oleh spermatozoa manusia tidak boleh dibiakkan in vitro lebih dari 14 hari (tidak termasuk waktu simpan beku).

9. Dilarang melakukan penelitian atau eksperimen terhadap atau menggunakan ovarium, spermatozoa atau embrio tanpa seijin dari pemilik ovarium atau spermatozoa.

10. Dilarang melakukan fertilisasi trans-spesies, kecuali fertilisasi tran-spesies tersebut diakui sebagai cara untuk mengatasi atau mendiagnosis infertilitas pada manusia. Setiap hybrid yang terjadi akibat fertilisasi trans-spesies harus diakhiri pertumbuhannya pada tahap 2 sel.

Dalam Keputusan Menteri tersebut pada point ke-4 telah dengan tegas melarang praktik surogasi/sewa rahim dilakukan dalam bentuk apapun di Indonesia.

\section{c. Peraturan Pemerintah Nomor 61 Tahun 2014 tentang Kesehatan Reproduksi}

Pada Pasal 1 angka (10) dimana menyebutkan pengertian dari Reproduksi dengan Bantuan atau Kehamilan di Luar Cara Alamiah adalah upaya memperoleh kehamilan di luar cara alamiah tanpa melalui proses hubungan seksual antara suami dan istri apabila cara alami tidak memperoleh hasil.

Dan Pasal 40 ayat (1) menyatakan bahwa Reproduksi dengan Bantuan atau Kehamilan di Luar Cara Alamiah hanya dapat dilakukan pada pasangan suami istri yang terikat perkawinan yang sah dan mengalami ketidaksuburan atau infertilitas untuk memperoleh keturunan.

Lanjut pada Pasal 40 ayat (2) : Reproduksi dengan Bantuan atau Kehamilan di Luar Cara Alamiah sebagaimana dimaksud pada ayat (1) dilaksanakan dengan menggunakan hasil pembuahan sperma dan ovum yang berasal dari suami dan istri yang bersangkutan dan ditanamkan dalam rahim istri dari mana ovum berasal.

Ayat (3): Reproduksi dengan Bantuan atau Kehamilan di Luar Cara Alamiah sebagaimana dimaksud pada ayat (1) dilakukan sesuai dengan perkembangan ilmu pengetahuan dan teknologi serta tidak bertentangan dengan norma agama.

Ayat (4): Reproduksi dengan Bantuan atau Kehamilan di Luar Cara Alamiah sebagaimana dimaksud pada ayat (1) harus dilakukan oleh tenaga kesehatan yang mempunyai kompetensi dan kewenangan.

Pasal 43 ayat (1) menyatakan bahwa: Kelebihan embrio hasil pembuahan di luar tubuh manusia (fertilisasi in vitro) yang tidak ditanamkan pada rahim harus disimpan sampai lahirnya bayi hasil Reproduksi dengan Bantuan atau Kehamilan di Luar Cara Alamiah.

Ayat (2): Penyimpanan kelebihan embrio sebagaimana dimaksud pada ayat (1) dapat diperpanjang setiap 1 (satu) tahun atas keinginan pasangan suami-istri untuk kepentingan kehamilan berikutnya.

Ayat (3) berbunyi: Kelebihan embrio sebagaimana dimaksud dalam ayat (2) dilarang ditanam pada:

a. Rahim ibu jika ayah embrio meninggal atau bercerai; atau

b. Rahim perempuan lain. 
Dapat ditarik suatu kesimpulan dari Pasal-Pasal diatas bahwa program kehamilan di luar cara alami dengan bantuan teknologi medis diantaranya:

1. Hanya dapat dilakukan oleh pasangan suami-istri yang terikat dalam hubungan perkawinan yang sah.

2. Hanya dapat dilakukan oleh pasangan suami-istri yang mengalami ketidaksuburan/infertilitas sehingga tidak dapat memperoleh keturunan.

3. Sperma dan sel telur yang diambil hanya diperbolehkan berasal dari pasangan suami-istri yang sah.

4. Setelah terjadinya pembuahan, embryo tersebut hanya boleh ditransfer kedalam rahim istri dari mana ovum berasal.

5. Jika terdapat kelebihan embrio maka dapat disimpan sampai lahirnya bayi hasil reproduksi buatan tersebut

6. Kelebihan embrio tidak dapat ditanamkan ketika ayah biologis dari embrio telah meninggal/bercerai dengan istrinya, dan

7. Dalam Pasal 43 ayat (3) huruf b menegaskan bahwa tidak boleh menitipkan/menanamkan embrio pada perempuan lain yang bukan istrinya dalam hal ini adalah ibu pengganti/surrogate mother.

\section{d. Kedudukan Surrogacy Agreement dalam Hukum Perjanjian di Indonesia}

Praktik sewa rahim juga merupakan sebuah perjanjian sehingga segala sesuatunya diatur dalam KUHPerdata. Pengertian perjanjian dalam Pasal 1313 KUHPerdata menyatakan bahwa "Suatu perbuatan dengan mana satu orang atau lebih mengikatkan dirinya terhadap satu orang lain atau lebih".

Disamping pengertian perjanjian dalam KUHPerdata, beberapa pendapat mengemukakan sebagai berikut: suatu perjanjian adalah suatu peristiwa dimana seorang berjanji kepada seorang yang lain atau dimana dua orang itu saling berjanji untuk melaksanakan sesuatu hal. Dari perjanjian ini maka timbulah yang namanya perikatan.Dalam bentuknya, perjanjian itu suatu rangkaian perkataan yang mengandung janji-janji atau kesanggupan yang diucapkan atau ditulis. ${ }^{8}$ Perjanjian adalah suatu peristiwa dimana pihak yang satu berjanji kepada phak lainnya untuk melakukan suatu hal, dari perjanjian tersebut maka muncul suatu hubungan hukum antara kedua belah pihak yang dinamakan dengan perikatan. ${ }^{9}$

Pengertian surrogacy agreement ialah suatu perbuatan hukum antara pasangan suami dan istri dengan ibu pengganti/surrogate mother, untuk saling mengikatkan diri demi memperoleh keturunan. Kemudian perjanjian tersebut menimbulkan hak dan kewajiban yang mana bahwa hak dari pasangan suami-istri tersebut adalah mendapatkan anak dari surrogate mother, dan kewajiban surrogate mother adalah hamil, mengandung dan melahirkan anak yang kemudian diberikan kepada pasangan suami-istri tersebut, hak dari surrogate mother adalah dibiayai selama kehamilan sampai proses persalinan oleh pasangan suami-istri dan kewajiban pasangan suami-istri tersebut adalah untuk membiayai segala keperluan surrogate mother dari awal hingga proses persalinan. ${ }^{10}$

\footnotetext{
${ }^{8}$ Subekti, Hukum Perjanjian, (Jakarta: PT. Intermasa, 1990), 1.

${ }^{9}$ CST. Kansil, Pokok-Pokok Pengetahuan Hukum Dagang Indonesia, (Jakarta: Sinar Grafika, 1994), 188.

${ }^{10}$ Sonny Dewi Judiasih, dkk., Aspek Hukum Sewa Rahim dalam Perspektif Hukum Indonesia, (Bandung: PT Refika Aditama, 2016), 63.
} 
Dalam KUHPerdarta terdapat beberapa Pasal yang dapat mengkaji mengenai praktik sewa rahim, diantaranya Pasal 1320 dan Pasal 1338 KUHPerdata. Pasal 1320 mengatur tentang syarat sahnya suatu perjanjian terdiri dari beberapa unsur, diantaranya:

1. Kesepakatan Para Pihak yang Membuat Perjanjian

Dalam hal ini kesepakatan merupakan persesuaian antara kehendak dan pernyataan yang dibuat oleh kedua belah pihak, dalam artian pihak-pihak tersebut setuju terhadap ketentuanketentuan dari isi perjanjian, para pihak harus memiliki kemauan yang bebas untuk mengikatkan diri tanpa adanya paksaan, kekhilafan dan penipuan.

Dalam perjanjian sewa rahim, sesuai dalam Pasal 1320 KUHPerdata maka harus ada kesepakatan secara sukarela tanpa ada unsur paksaan dan penipuan antara pihak penyewa (pasangan suami-istri) dengan ibu pengganti.

2. Kecakapan dalam Membuat Perjanjian

Dalam kontrak sewa rahim ini antara penyewa dengan ibu pengganti harus cakap menurut hukum untuk bertindak sendiri. Berdasarkan Pasal 1330 KUHPerdata, pihak yang termasuk cakap hukum diantaranya: orang yang sudah dewasa (berumur diatas 21 tahun), tidak berada di bawah pengampuan (Curatele), tidak sakit/gila.

3. Suatu Hal Tertentu

Sesuatu yang diperjanjikan haruslah jelas, suatu hal tertentu merupakan pokok perjanjian, objek perjanjian, prestasi yang wajib dipenuhi. Dalam kontrak sewa rahim ini, yang menjadi objek perjanjian adalah jasa dari ibu pengganti dalam menggantikan proses kehamilan dan kelahiran. Adapun yang menjadi objek perikatan dinamakan "Prestasi" dimaksud dalam Pasal 1234 KUHPerdata. Dalam hal ini ibu pengganti memberikan jasa berupa penyewaan rahim, perawatan bayi di dalam kandungan hingga sampai pada proses melahirkan.

4. Suatu Sebab yang tidak Terlarang

Pada kontrak penyewaan rahim, yang menjadi sebab perjanjian atau tujuan dari isi perjanjian setiap orang berbeda-beda.Ada yang karena memang tidak ingin mengandung dan melahirkan, ada juga yang karena kondisi fisik istri yang tidak memungkinkan sehingga mustahil dapat mengandung.

Pasal 1338 ayat (1) KUHPerdata menyatakan bahwa semua kontrak (perjanjian) yang dibuat secara sah berlaku sebagai undang-undang bagi mereka yang membuatnya. Konklusi dari Pasal ini bahwa meskipun terdapat asas kebebasan berkontrak namun kebebasan ini tetap dibatasi oleh hukum.Tidak terpenuhinya syarat obyektif pada Pasal 1320 KUHPerdata "suatu sebab yang tidak dilarang" mengakibatkan perjanjian menjadi batal.Pasal ini juga memiliki kolerasi dengan Pasal 1337 KUHPerdata, yang menyatakan bahwa "suatu sebab adalah terlarang, apabila dilarang oleh undang-undang, atau apabila berlawanan dengan kesusilaan baik atau ketertiban umum". Kedua Pasal ini saling berhubungan menjelaskan bentuk dari sebab yang tidak bertentangan dan dilarang oleh undang-undang, kesusilaan dan ketertiban umum. Sebenarnya pelarangan mengenai ibu pengganti/Surrogate Mother terdapat dalam UndangUndang Nomor 36 Tahun 2009 tentang Kesehatan pada Pasal 127.

\section{Akibat Hukum terhadap Anak yang dihasilkan dari Praktik Sewa Rahim dalam Hukum Positif Indonesia}

Islam hanya mengakui ikatan perkawinan sebagai landasan bagi keluarga, apabila praktik sewa rahim dihalalkan maka akan menimbulkan kerancuan pada konsep keluarga dan kekerabatan yang diatur secara ketat oleh hukum Islam. Pada Pasal 99 Kompilasi Hukum Islam 
menjelaskan bahwa anak yang sah merupakan 1. anak yang dilahirkan dalam perkawinan yang sah; 2. hasil perbuatan suami istri di luar rahim dan dilahirkan oleh istri tersebut. ${ }^{11}$ Pada ayat kedua pasal tersebut nampak bahwa KHI tidak melegalkan praktik penyewaan rahim, yang diperbolehkan oleh KHI adalah praktik kehamilan di luar cara alamiah yang dilahirkan oleh rahim istri. Dalam Pasal 42 UU tentang Perkawinan juga menjelaskan bahwa anak sah adalah anak yang lahir dalam atau sebagai akibat dari pekawinan yang sah. ${ }^{12}$ Dari bunyi pasal tersebut dapat diketahui bahwa anak hasil dari penyewaan rahim bukanlah anak yang sah dari suami-istri penyewa, akan tetapi akan menjadi anak sah dari ibu pengganti dan suaminya (jika ibu pengganti tersebut memiliki suami). Namun jika Ibu Pengganti belum memiliki suami maka status anak tersebut akan menjadi anak luar kawin, merujuk pada Pasal 43 ayat 1 UU Perkawinan bahwa anak yang dilahirkan di luar perkawinan hanya mempunyai hubungan perdata dengan ibunya dan keluarga ibunya. "Ibunya" dalam pasal tersebut yakni Ibu Pengganti dimana yang telah melahirkan anak tersebut.

Dalam menentukan anak hasil dari sewa rahim dapat dilihat terlebih dahulu status perkawinan dari Ibu Pengganti, jika dia tidak/belum memiliki suami maka anak yang dilahirkan akan berstatus anak luar kawin, sedangkan jika Ibu Pengganti tersebut terikat dalam perkawinan yang sah maka anak yang dilahirkan akan berstatus sebagai anak sah dari Ibu Pengganti beserta suaminya karena lahir dalam perkawinan yang sah. Hal ini akan berimbas pula terhadap hak waris dari anak yang dilahirkan, apabila status anak merupakan anak yang sah maka ia berhak mendapatkan hak waris dari orang tua sahnya yakni Ibu Pengganti dan suaminya. Namun jika status anak tersebut merupakan anak luar kawin maka ia memiliki hubungan waris mewarisi dengan pihak ibunya saja, yakni Ibu Pengganti.

\section{Pelaksanaan Sewa Rahim dalam Perspektif Hukum Islam}

Allah SWT memang telah menciptakan perempuan-perempuan yang memiliki kekurangan yakni tidak bisa melahirkan keturunan, dalam firman-Nya surat Asy-Syura (42) ayat 49-50:

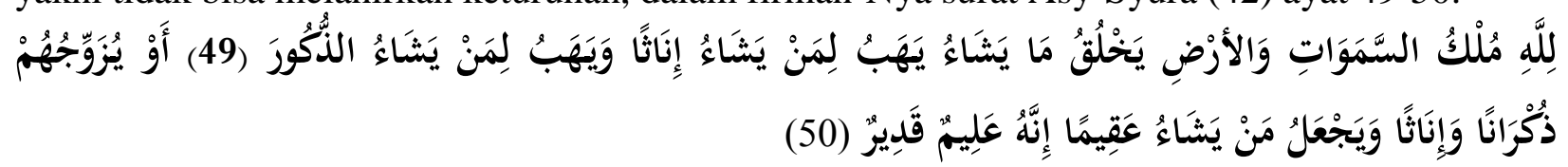

"Milik Allahlah kerajaan langit dan bumi; Dia menciptakan apa yang dia kehendaki, memberikan anak perempuan kepada siapa yang Dia kehendaki, dan memberikan anak laki-laki kepada siapa yang Dia kehendaki." (49)

"Atau Dia menganugerahkan jenis laki-laki dan perempuan, dan menjadikan mandul siapa yang Dia kehendaki. Dia Maha Mengetahui, Maha Kuasa.” (50)

Para ulama telah melarang penggunaan teknologi bayi tabung dari pasangan suami-istri yang dititipkan di rahim perempuan lain. "itu hukumnya haram," papar MUI dalam fatwanya, Nomor: Kep-952/MUI/XI/1990 tentang inseminasi buatan/Bayi Tabung. Dalam keputusan tersebut dijelaskan bahwa : Inseminasi buatan/bayi tabung dengan sperma dan ovum yang diambil secara muhtarom dari pasangan suami dan istri untuk istri-istri yang lain hukumnya haram/tidak dibenarkan dalam Islam. ${ }^{14}$

\footnotetext{
${ }^{11}$ Kompilasi Hukum Islam, Pasal 99.

${ }^{12}$ UU No 1 Tahun 1974 tentang Perkawinan, Pasal 42.

${ }^{13}$ UU No 1 Tahun 1974 tentang Perkawinan, Pasal 43.

${ }^{14}$ Yusuf Yudi Prayudi, Fatwa bayi Tabung, diakses pada 29 Oktober 2007.
} 
Menurut Fatwa MUI pada tanggal 26 Mei 2006, berkaitan dengan masalah bayi tabung, Majelis Ulama Indonesia mengeluarkan empat buah fatwa, ${ }^{15}$ yaitu:

a. Bayi tabung dengan sperma dan ovum dari pasangan suami isteri yang sah hukumnya mubah (boleh), sebab hak ini termasuk ikhiar berdasarkan kaidah-kaidah agama.

b. Bayi tabung dari pasangan suami-isteri dengan titipan rahim isteri yang lain (misalnya dari isteri kedua dititipkan pada isteri pertama) hukumnya haram berdasarkan kaidah Sadd azzari'ah, sebab hal ini akan menimbulkan masalah yang rumit dalam kaitannya dengan masalah warisan (khususnya antara anak yang dilahirkan dengan ibu yang mempunyai ovum dan ibu yang mengandung kemudian melahirkannya, dan sebaliknya).

c. Bayi tabung dari sperma yang dibekukan dari suami yang telah meninggal dunia hukumnya haram berdasarkan kaidah Sadd az-zari'ah10 sebab hal ini akan menimbulkan masalah yang pelik, baik dalam kaitannya dengan penentuan nasab maupun dalam kaitannya dengan hal kewarisan.

d. Bayi tabung yang sperma dan ovumnya diambil dari selain pasangan suami isteri yang sah hukumnya haram, karena itu statusnya sama dengan hubungan kelamin antar lawan jenis di luar pernikahan yang sah (zina), dan berdasarkan kaidah Sadd az-zari'ah, yaitu untuk menghindarkan terjadinya perbuatan zina sesungguhnya.

Namun demikian terdapat fatwa lain yang dikeluarkan oleh Majelis Mujamma' Fiqih Islami, yang menyatakan bahwa:

Pertama, lima perkara berikut diharamkan dan terlarang sama sekali, karena dapat mengakibatkan percampuran nasab dan hilangnya hak orang tua serta perkara-perkara lain yang dikecam oleh syari'at.

a. Sperma yang diambil dari pihak lelaki disemai dengan indung telur pihak wanita yang bukan istrinya kemudian dicangkokkan ke dalam rahim istinya.

b. Indung telur yang diambil dari pihak wanita disemaikan kepada sperma yang diambil dari pihak yang bukan suaminya kemudian dicangkokkan ke dalam rahim si wanita.

c. Sperma dan indung telur yang disemaikan tersebut diambil dari pasangan suami-istri, kemudian dicangkokkan ke dalam rahim si istri.

d. Sperma dan indung telur yang disemaikan tersebut diambil dari seorang suami dan istrinya, kemudian dicangkokkan ke dalam rahim istrinya yang lain.

Kedua, dua perkara berikut ini yang dibolehkan jika memang sangat dibutuhkan dan setelah memastikan keamanan dan keselamatan yang harus dilakukan sebagai berikut:

a. Sperma tersebut diambil dari si suami dan indung telurnya diambil dari istrinya, kemudian disemaikan dan dicangkokkan ke dalam rahim istrinya.

b. Sperma si suami diambil kemudian disuntikkan ke dalam saluran rahim istrinya atau langsung ke dalam rahim istrinya untuk disemaikan.

Hasil dari ijtihad tersebut mengharamkan penggunaan teknik bayi tabung yang menggunakan sperma dan ovum dari pasangan suami-istri yang kemudian embrionya ditransplantasikan ke dalam rahim wanita lain. dengan demikian jelaslah status anak yang

${ }^{15}$ Depag RI, Himpunan Fatwa Majelis Ulama Indonesia, Dirjen Bimas Islam dan Penyelenggaraan Haji, 
dilahirkan oleh wanita tersebut disamakan dengan anak zina dan para ulama juga menegaskan, dikemudian hari hal itu akan menimbulkan masalah yang rumit kaitannya dengan warisan. ${ }^{16}$

Mengenai masalah bayi tabung dan sewa rahim merupakan persoalan baru yang tidak disebutkan dalam kitab-kitab fiqh dimana kita dapat mencari dasar hukumnya, khususnya dalam hal sewa rahim, maka banyak bermunculan pendapat-pendapat dari cendikiawan muslim, yang mana dari pendapat-pendapat tersebut ada yang mengharamkan dan ada juga yang menghalalkan, di antara pendapat-pendapat yang mengharamkan:

a. Menurut Syaikh Mahmud Syaltut (1963)

Jika inseminasi itu dari sperma laki-laki lain yang tidak terikat dengan akad perkawinan dengan wanita, maka sesungguhnya hal tersebut mendorong ketaraf kehidupan hewan dan tumbuh-tumbuhan dan mengeluarkannya dari harkat kemanusiaan, yaitu harkat kemasyarakatan yang luhur yang dipertautkan dalam jalinan perkawinan yang telah disebar luaskan.Dan jika inseminasi buatan untuk manusia itu bukan dari sperma suami, maka hal tersebut statusnya sebagai sesuatu yang buruk sekali dan sesuatu kejahatan yang lebih munkar dari memungut anak. $^{17}$

b. Pendapat Mu'tamar Tarjih Muhammadiyah tahun 1980

Sewa rahim tidaklah dibenarkan dalam hukum Islam, karena termasuk menanamkan benih pada rahim wanita lain merupakan haram hukumnya, sebagaimana sabda Rasulullah SAW :

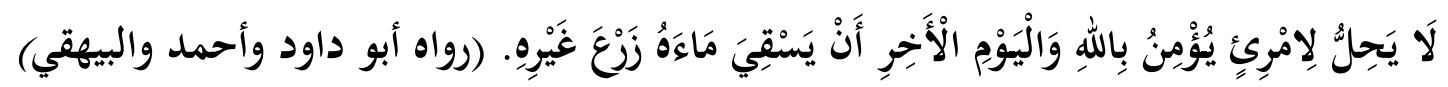

"Tidak halal bagi seorang beriman kepada Allah dan Hari Akhir untuk menyiramkan airnya ke ladang orang lain" (HR Abū Dāwūd). ${ }^{18}$

Demikian pula di haramkan karena yang pertama, pembuahan semacam itu termasuk kedalam kejahatan yang dapat menurunkan mantabat manusia, dan kedua dapat merusak tata hukum yang telah di bina dalam kehidupan masyarakat. ${ }^{19}$

c. Pendapat Munas Alim Ulama' (NU) di Sukorejo Situbondo tahun 1983

Haram hukumnya menyewakan rahim bagi suami dan istri, hal ini berdasarkan hadis Nabi yang terdapat pada Tafsir Ibnu Katsir Juz 3/326, Rasulullah bersabda: "Tidak ada dosa yang lebih besar setelah syirik di bandingkan seseorang yang menaruh spermanya di rahim wanita lain yang tidak halal baginya". Jika terdapat kasus semacam itu, menurut pendapat peserta munas, dalam hal nasab, kewalian dan hadlanah tidak bisa dinisbatkan kepada pemilik sperma menurut Imam Ibnu Hajar, karena masuknya tidak muhtarom.Yang dimaksud dengan sperma yang muhtarom adalah hanya ketika keluarnya saja, sebagaimana yang dianut oleh Imam Ramli, walaupun menjadi tidak terhormat ketika masuk (ke vagina orang lain).

d. Hasil sidang Lembaga Fiqh Islam OKI III di Yordania tahun 1986

\footnotetext{
${ }^{16}$ Husni Thamrin, Aspek Hukum Bayi Tabung dan Sewa Rahim, Perspektif Hukum Perdata dan Hukum Islam, (Yogyakarta: Aswaja Pressindo, 2014), 93-96.

${ }^{17}$ Abdul Salam Arief, "Pembaruan Pemikiran Hukum Islam, Antara Fakta dan Realit, Kajian Pemikiran Hukum Syaikh Mahmud Syaltut”, (Yogyakarta: LESFI: 2003), 165.

${ }^{18} \mathrm{Abū}$ Dāwūd, Sunan $A b \bar{\imath} D \bar{a} w \bar{u} d$, diedit oleh al-Arna'ūṭ (Beirut: Dār ar-Risālah al-'Ālamiyyah, 1430/2009), III: 487, hadis nomor 2158.

${ }^{19}$ Imam Banjuri, Penitipan Pra Embrio Pada Rahim Wanita Lain (Sewa Rahim) menurut Hukum Islam, (Ponorogo: Jurnal Hukum dan Ekonomi Islam ISID, 2011), 269.
} 
Menetapkan bahwa hukum sewa rahim adalah haram dan di larang mutlak bagi dirinya karena akan mengakibatkan tercampurnya nasab dan hilangnya keibuan dan halangan-halangan syar'i lainnya, begitu pula tidak dibenarkan menitipkannya ke rahim istri yang kedua, ketiga dan seterusnya bagi yang berpoligami.

\section{e. Dr. Yusuf al-Qardawi}

Berpendapat bahwa penyewaan rahim tidak diperbolehkan, karena akan menimbulkan pertanyaan yang membingungkan, mulai dari "siapakah ibu dari bayi tersebut, apakah si pemilik sel telur yang membawa karakteristik keturunan, ataukah yang telah melahirkannya, yang menderita dan menanggung rasa sakit karena hamil dan melahirkan?" padahal, ia hamil dan melahirkan bukn atas kemauannya sendiri. ${ }^{20}$

Adapun pendapat-pendapat yang menghalalkan di antaranya:

a. $\quad$ Prof. Dr. Jurnalis Udin, PAK.

Apabila rahim istri porgam fertilisasi in vitro memenuhi syarat dapat mengandung bayi hingga lahir, maka hukum sewa rahim adalah haram. Akan tetapi apabila; (a) rahim istri memiliki kecacatan, (b) belum ditemukan teknologi yang dapat mengandung embrio itu hingga lahir, dan (c) karena dengan melalui sewa rahim merupakan satu-satunya jalan untuk mendapatkan anak dari benihnya sendiri,maka hukumnya menjadi mubah, karena hal itu dilakukan dalam keadaan darurat, keinginan memiliki anak yang sangat besar. ${ }^{21}$

b. H. Ali Akbar

Menitipkan bayi dalam rahim wanita lain hukumnya adalah boleh, karena si ibu tidak dapat mengandungnya, sedang menyusukan anak kepada wanita lain diperbolehkan dalam Islam, malah boleh diberi upah. Maka boleh pula memberikan upah pada wanita yang meminjamkan rahimnya. ${ }^{22}$

c. H. Salim Dimyati

Yang dilahirkan dari ibu pengganti tidak lain adalah anak angkat belaka, tidak ada hak mewarisi dan di warisi, karena anak angkat bukanlah anak sendiri, tidak boleh disamakan dengan anak kandung. ${ }^{23}$

\section{Analisis}

Ketika hendak mengkaji praktik sewa rahim, maka perlu dikaji dengan menggunakan metode ijtihad yang lazim digunakan oleh para mujtahid/ahli ijtihad, agar hukum yang diciptakan sesuai dengan prinsip-prinsip syari'ah. Dengan menggunakan pendekatan multidisipliner maka akan ditemukan hukum yang proporsional dan mendasar.

Menempatkan benih suami pada rahim istri baik yang dilakukan secara alami maupun dengan melalui perantara/alat bantu (teknologi medis) maka menurut ajaran Islam adalah halal, karena keduanya berada dalam suatu ikatan yang sah, Allah berfirman dalam Qur'an Surah alBaqarah ayat 233:

"Istri-istrimu adalah lading bagimu. Maka datangilah ladangmu itu kapan saja dengan cara yang kamu sukai. Dan utamakanlah (yang baik) untuk dirimu. Bertakwalah kepada Allah dan ketahuilah bahwa kamu (lelaki) kelak akan menemui-Nya. Dan sampaikan kabar gembira kepada orang yang beriman."

\footnotetext{
${ }^{20}$ Yusuf Qardawi, Fatwa'Fatwa Kontemporer, (Jakarta: Gema Insani Press, Jilid III, 2002), 659-660.

${ }^{21}$ Salim HS, Bayi Tabung dalam Bidang Pengobatan, (Jakarta: Sinar Grafika, 1993), 114.

${ }^{22}$ Umar Shihab, Hukum Islam dan Transformasi Pemikiran (Semarang: Dina Utama, 1996), 141.

${ }^{23} \mathrm{Ibid}, 141$.
} 


\section{Siapakah yang disebut dengan Ibu?}

Ketika suatu praktik sewa rahim terjadi maka akan menimbulkan suatu permasalahan hukum, yakni kepada siapakah anak tersebut dinasabkan? Apakah kepada pemilik embrio atau kepada ibu yang telah melahirkannya? Islam mengatur bagaimana seorang wanita dapat disebut sebagai ibu sejati, karena dalam Al-Qur'an telah di tegaskan, antara lain dalam surat alMujadalah ayat 2:

Dan dalam surat al-Mujadilah (58) ayat 2 Allah SWT berfirman:

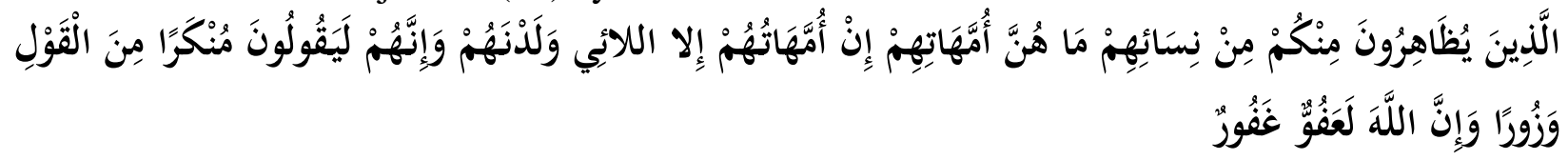

Orang-orang diantara kamu yang menceraikan istrinya dengan zihar, bukanlah istrinya itu ibunya.Ibu mereka hanyalah (perempuan) yang melahirkannya, dan mereka sungguh menggunakan kata-kata yang mungkar dan dusta.Tapi sungguh, Allah Maha Pemaaf, Maha Pengampun.

Surat Al-Ahqaf (46) ayat 15 :

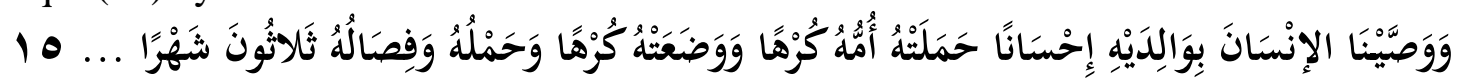

Dan Kami perintahkan kepada manusia supaya berbuat baik kedua orang tuanya, Ibunya mengandungnya dengan susah payah dan melahirkannya dengan susah payah (pula). Masa mengandung sampai menyapihnya selama tiga puluh bulan....

Surat Al-Luqman (31) ayat 14 yang berbunyi :

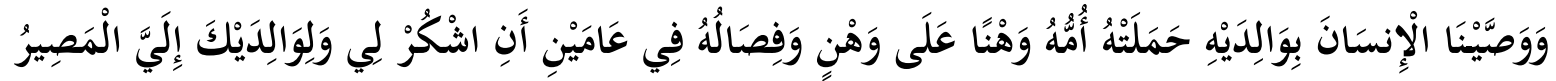

Dan Kami perintahkan kepada manusia (agar berbuat baik) kepada orang tuanya. Ibunya telah mengandungnya dalam keadaan lemah yang bertambah-tambah, dan menyapihnya dalam usia dua tahun, bersyukurlah kepada-Ku dan kepada orang tuamu. Hanya kepada aku kembalimu.

Dari ayat-ayat yang telah dipaparkan diatas jelas bahwa yang dimaksud dengan ibu ialah orang yang telah melahirkan kita. Sewa rahim tidak dibenarkan dalam Hukum Islam, sebab akan menimbulkan pencampuradukan dan penghilangan nasab, yang telah diharamkan oleh ajaran Islam. Hal tersebut juga termasuk kehamilan dan kelahiran melalui proses perzinaan, hanya saja di dalam prosesnya tidak terjadi penetrasi penis ke dalam vagina.

\section{Konsep Darurat dalam Sewa Rahim}

Wahhab Az-Zuhaili dalam bukunya mendefinisikan arti kata darurat/dharurriyat sebagai sesuatu yang tidak dapat ditinggalkan baik dalam kehidupan manusia maupun dalam perihal keagamaan, jika sesuatu tersebut tidak ada maka kehidupan di dunia ini akan rusak, kenikmatan hilang, dan akan mendapat siksaan di akhirat. ${ }^{24}$

Para ulama' sepakat memberikan persyaratan bagi seseorang bisa dikatakan dalam keadaan darurat harus terdapat 5 syarat, syarat-syarat tersebut adalah;

${ }^{24}$ Wahhab Az-Zuhaili, Nazhariyah al-Dlarurah al-Syar'iyah, diterjemahkan oleh Said Agil Husain alMunawar, dkk., Konsep Darurat Dalam Hukum Islam: Studi Banding Dengan Hukum Positif, (Jakarta: Gaya Media Pratama, 1997), 51. 
1. Kondisi bahaya besar itu telah benar-benar terjadi atau belum terjadi, namun diyakini atau diprediksi kuat akan terjadi.

2. Tidak bisa dihilangkan dengan cara yang halal.

3. Ukuran melanggar larangan saat kondisi terpaksa itu harus dilakukan sekadarnya saja.

4. Waktu melanggar larangan saat kondisi darurat ini tidak boleh melebihi waktu darurat tersebut.

5. Melanggar sesuatu yang terlarang dalam kondisi darurat tersebut tidak akan menimbulkan bahaya yang lebih besar. adalah: ${ }^{25}$

Dalam prakteknya para ulama' memberikan pengecualian pada kaidah ini, diantaranya

Pertama, apabila ketika menghilangkan kemudlaratan dapat mengakibatkan datangnya kemudlaratan yang lain yang sama tingkatannya, maka hal ini tidak diperbolehkan melakukan kemudlaratan tersebut. Seperti seseorang yang kelaparan mengambil makanan orang lain yang juga dalam kelaparan, meskipun orang yang pertama juga kelaparan. Kedua, apabila dalam menghilangkan kemudlaratan menimbulkan kemudlaratan yang lain yang lebih besar atau lebih tinggi tingkatannya, maka hal ini lebih tidak diperbolehkan. Selain itu, dalam menghilangkan kemudlaratan, dilarang melampaui batas dan betul-betul tidak ada jalan lain kecuali melakukan perbuatan yang dilarang itulah satu-satunya jalan.

Seperti yang telah disampaikan sebelumnya bahwa tujuan dari sewa rahim adalah untuk memperoleh keturunan dari benih sendiri dengan menggunakan bantuan teknologi medis dikarenakan rahim istri tidak dapat memproses janinnya. Akan tetapi dalam kasus sewa rahim perlu dibedakan antara hajat dengan darurat, bahwa sewa rahim tidak bisa dikatakan kondisi yang darurat, jangan sampai orang terpaksa melakukan sewa rahim dengan mengabaikan prinsipprinsip syari'at yang pokok, berupa memelihara hak-hak orang lain, menciptakan keadilan, menunaikan amanah, dan menghindari kemudaratan.

Dalam kasus sewa rahim ini, penulis beranggapan bahwa keinginan untuk memiliki anak bukanlah suatu hal yang darurat, dan hal tersebut hanya sebuah keinginan manusiawi, yang apabila tidak dilakukan tidak akan menimbulkan sesuatu yang berbahaya, dan sebaliknya apabila dilakukan maka akan menimbulkan berbagai persoalan, seperti kerancuan status anak baik dalam hal nasab, kewalian dan kewarisan, dan beban psikologis dari pihak suami, istri juga wanita yang di sewa rahimnya. Karena sewa rahim akan memunculkan masalah baru yang lebih rumit, maka sewa rahim di hukumi haram.

Disamping itu dalam kaidah fiqh juga dikenal istilah;

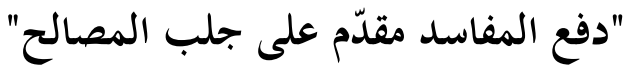

"Mencegah kerusakan lebih didahulukan daripada mengambil kemaslahatan"

Seluruh pekerjaan manusia pasti ada yang membawa kepada kemaslahatan dan ada pula yang menimbulkan kemafsadatan, baik kedua hal tersebut untuk kepentingan duniawiyah maupun untuk kepentingan $u k h r a w i y a h .{ }^{26}$ Kaidah Fiqh diatas berlaku ketika berkumpul antara maslahat dan mafsadat, maka yang harus dipilih/didahulukan adalah sesuatu yang maslahatnya

${ }^{25}$ A. Jazuli, Kaidah-kaidah Fikih, Kaidah-kaidah Hukum Islam dalam Menyelesaikan Masalah-Masalah yang Praktis, (Jakarta; Kencana Prenada Media Group, 2007), 70.

${ }^{26}$ A. Djazuli, Kaidah-Kaidah Fikih, Kaidah-Kaidah Hukum Islam dalam Menyelesaikan Masalah-Masalah yang Praktis, (Jakarta:Kencana, 2006), 27. 
lebih banyak/lebih kuat, dan apabila antara maslahat dan mafsadat sama besarnya maka lebih utama mendahulukan maslahat dan menolak mafsadahnya, karena dalam hal ini tindakan menolak mafsadah sudah merupakan kemaslahatan. ${ }^{27}$

Praktik sewa rahim pada umumnya dilakukan untuk memperoleh keturunan karena rahim istri tidak dapat memproses janin. Hal tersebut tentu merupakan suatu kemaslahatan bagi pasangan suami-istri yang ingin memperoleh keturunan, namun disamping itu mudharat yang ditimbulkannya akan jauh lebih banyak, seperti akan tercampurnya nasab, tidak jelas siapa orang tua dari anak tersebut, hilangnya sifat keibuan, dll. Dan praktik sewa rahim ini juga tidak bisa dikategorikan sebagai sesuatu yang mendesak/darurat, seperti yang telah dijelaskan sebelumnya bahwa praktik sewa rahim ini hanyalah sebuah keinginan/hajat manusiawi, yang apabila tidak dilakukan tidak akan menimbulkan sesuatu yang berbahaya, dan sebaliknya apabila dilakukan maka akan menimbulkan berbagai persoalan.

\section{Kesimpulan}

Sewa rahim adalah sebuah alternatif ketika istri memiliki kecacatan dalam rahimnya, sehingga rahimnya tidak bisa mengandung dan melahirkan bayinya. Dengan melalui ibu Pengganti/Surrogate mother yang merupakan seorang wanita yang mengandung anak atas kepentingan orang lain dan juga memberikan hak-haknya sebagai orang tua kepada orang lain tersebut, atau seorang wanita mengandung yang anak benihnya berasal dari pasangan lain dan kemudian setelah melahirkan wanita tersebut memberikan hak atas pengasuhan anak yang telah dilahirkannya kepada pasangan yang menitipkan benihnya tersebut.

Dalam hukum positif ada beberapa aturan yang secara tersirat melarang praktik sewa rahim ini, diantaranya UU No.Undang-Undang No. 36 Tahun 2009 tentang Kesehatan, UndangUndang ini merupakan pembaruan dari Undang-Undang No. 23 Tahun 1992 Tentang Kesehatan.Keputusan Menteri Kesehatan RI No. 72/Menkes/Per/II/1999 tentang Penyelenggaraan Teknologi Reproduksi Buatan.Peraturan Pemerintahan Nomor 61 Tahun 2014 tentang Kesehatan Reproduksi.Dan kedudukan Surrogacy Agreement dalam Hukum Perjanjian di Indonesia juga dianggap tidak memenuhi persyaratan sah dari hukum perjanjian di Indonesia.

Dalam kalangan cendekiawan Muslim terdapat berbagai macam pandangan terkait praktik sewa rahim ini, ada yang mengharamkan dan ada pula yang menghalalkan.Diantara pendapat yang melarangnya lebih meninjau dari segi sosial, dapat menarik ketaraf kehidupan seperti hewan dan pencampuran nasab. Segi etika, bahwa memasukkan benih ke rahim wanita lain hukumnya haram berdasarkan hadis Nabi serta bagi seorang wanita bisa menghilangkan sifat keibuannya dan dapat merusak tatanan kehidupan. Adapun pendapat yang membolehkan lebih menekankan pada konsep darurat, dimana keinginan untuk memperoleh keturunan sangatlah besar.Dalam penelitian ini penulis menyimpulkan bahwa praktik sewa rahim tidak dapat dikategorikan sebagai hal yang darurat dan mendesak, karena pelaku praktik sewa rahim ini tidak memenuhi persyaratan sebagai seseorang bisa dikatakan dalam keadaan darurat.

\section{DAFTAR PUSTAKA}

\footnotetext{
${ }^{27}$ Ibid., 29.
} 
Adil, Abu Abdurrahman Bin Yusuf Al Azazi, Pandangan Al-Qur'an dan Ilmu Kedokteran, diterjemahkan oleh Zaenal Mutaqin, dari Fathul Karim Bi Ahkamil Hamil wal janin, Darul Ibnu Al-Jauziyah, Cairo, (Bandung: Pustaka Rahmat, 2009).

Arief, Abdul Salam, Pembaruan Pemikiran Hukum Islam, Antara Fakta dan Realita, Kajian Pemikiran Hukum Syaikh Mahmud Syaltut, (Yogyakarta: LESFI, 2003).

Banjuri, Imam, "Penitipan Pra Embrio Pada Rahim Wanita Lain (Sewa Rahim) menurut Hukum Islam", Jurnal Hukum dan Ekonomi Islam ISID, 2011.

Caesa, Fadilla, "Perspektif Hukum Islam dan Aturan Hukum Yang Berlaku di Indonesia Terhadap Perjanjian Sewa Rahim dan Kedudukan Anak Yang Lahir Dari Sewa Rahim,” Jurnal Online Mahasiswa, Vol. 1 No. 1, 2016.

DEPAG RI, Himpunan Fatwa Majelis Ulama Indonesia, Dirjen Bimas Islam dan Penyelenggaraan Haji, 2003.

HS, Salim, Bayi Tabung dalam Bidang Pengobatan, Sinar Grafika, Jakarta1993).

Huminca, "Rahim Pinjaman Membawa Sengsara", (Bandung: Harian Pikiran Rakyat, 2014).

Ipandang, "Tanggung Jawab Manusia Terhadap Al-Maslahat (Kajian Ushul Fiqh)," Jurnal Al'Adl, Vol. 8, No. 2, 2015.

Jazuli, A., Kaidah-kaidah Fikih, Kaidah-kaidah Hukum Islam dalam Menyelesaikan MasalahMasalah yang Praktis, (Jakarta: Kencana Prenada Media Group, 2007).

Kansil, CST., Pokok-Pokok Pengetahuan Hukum Dagang Indonesia, (Jakarta: Sinar Grafika, 1994).

Keputusan Menteri Kesehatan RI No. 72/Menkes/Per/II/1999 tentang Penyelenggaraan Teknologi Reproduksi Buatan.

Khairatunnisa, "Keberadaan Sewa Rahim Dalam Perspektif Hukum Perdata", Lex Privatum, Vol. 3 No. 1, Januari-Maret 2015.

Kitab Undang-Undang Hukum Perdata Pasal 1320, 1337, 1338 tentang Perjanjian.

Kompilsai Hukum Islam

Peraturan Pemerintahan Nomor 61 Tahun 2014 tentang Kesehatan Reproduksi.

Qardawi, Yusuf, Fatwa-Fatwa Kontemporer Jilid III, (Jakarta: Gema Insani Press, 2002).

Rahmawati, Nurul Alifah, "Fenomena Surrogate Mother (Ibu Pengganti) Dalam Perspektif Islam Ditinjau Dari Hadis," Jurnal Nuansa, Vol. 14 No. 2, Juli-Desember 2017.

Ratman, Desriza, Surrogate Mother, dalam Perspektif Etika dan Hukum, (Jakarta: Elex Media Komputindo, 2012).

Sabilah, Sarah, "Penerapan Maqashid A-Syari'ah dalam Kasus Sewa Rahim”, Makalah, Magister Studi Islam FIAI UII, 2017.

Sabiq, Ahmad bin Abdul Lathif Abu Yusuf, Kondisi Darurat Membolehkan Sesuatu yang Terlarang, https://maktabahabiyahya.wordpress.com/2012/05/23/kaidah-kondisi-daruratmembolehkan-sesuatu-yang-terlarang/, di akses pada 27 April 2019.

Setiawan, Fajar Bayu, dll., "Kedudukan Kontrak Sewa Rahim dalam Hukum Positif Indonesia", Jurnal Privat Law, Edisi 01, 2013.

Shihab, Umar, Hukum Islam dan Transformasi Pemikiran, (Semarang: Dina Utama, 1996.

Sonny Dewi Judiasih dkk., Aspek Hukum Sewa Rahim dalam Perspektif Hukum Indonesia, (Bandung: Refika Aditama, 2016).

Subekti, Hukum Perjanjian, (Jakarta: Intermasa, 1990). 
Tandirerung, Dewi Astika, "Analisis Perjanjian Innominaat terhadap Peminjaman Rahim (Surrogate Mother) di Indonesia," Amanna Gappa, Vol. 26, No. 1, Maret 2018.

Thamrin, Husni, Aspek Hukum Bayi Tabung dan Sewa Rahim, Perspektif Hukum Perdata dan Hukum Islam, (Yogyakarta: Aswaja Pressindo, 2014).

Undang-Undang No. 1 Tahun 1974 Tentang Perkawinan

Undang-Undang Nomor 23 Tahun 1992 Tentang Kesehatan.

Undang-Undang Republik Indonesia Nomor 36 Tahun 2009 tentang Kesehatan.

Wardana, Ardian Arista, "Pengakuan Anak Di Luar Nikah: Tinjauan Yuridis Tentang Status Anak Di Luar Nikah,” Jurnal Jurisprudence, Vol. 6 No. 2, Desember, 2016.

Yasin Amka, Hukum Sewa Rahim tinjauan Fiqh Kontemporer, https://yasinamka. blogspot.com/2015/02/hukum-sewa-rahim-tinjauan-fiqh.html, di akses pada 27 April 2019. 